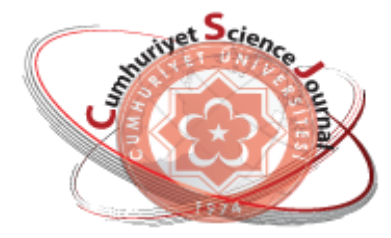

e-ISSN: $2587-246 X$

ISSN: 2587-2680

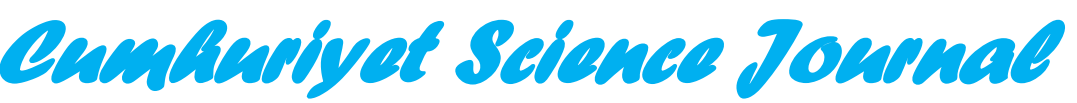

CST

Cumhuriyet Sci. J., Vol.39-3(2018) 608-614

\title{
Synthesis and Biological Evaluation of Novel 5,8-Dibromo-2-N-substituted- 1,4-Naphthoquinone Derivatives as Potential Antimicrobial Agents
}

\author{
Klymet BERKIL AKAR*, Eda MERCAN, Barış ERAN, Bilge Hilal ÇADIRCI \\ Gaziosmanpaşa University, Faculty of Engineering and Natural Science, Department of Genetic and \\ Bioengineering, Tokat, TURKEY
}

http://dx.doi.org/10.17776/csj.350308

\begin{abstract}
The seven 5,8-dibromo-2-N-substituted-1,4-naphthoquinone derivatives have been synthesized and tested for their in vitro antimicrobial activities. The results suggest that the synthesized 2-N-substituted-1,4naphthoquinones have high antimicrobial activity. The diffusion capacities of the compounds are also important for the determination of the antimicrobial activities; $2 \mathbf{c}, \mathbf{2} \mathbf{f}$ and $2 \mathbf{g}$ have been shown to be promising compounds for future studies.
\end{abstract}

Keywords: 1,4-Naphthoquinone, nucleophilic substitution, antimicrobial activity

\section{Potansiyel Antimikrobiyal Ajanlar Olarak Yeni 5,8-Dibromo-2-N- Sübstitüe-1,4-Naftokinon Türevlerinin Sentezi ve Biyolojik Değerlendirmesi}

\begin{abstract}
Özet. Yedi adet 5,8-dibromo-2-N-sübstitüe-1,4-naftakinon türevi sentezlenmiş ve bu bileşiklerin in vitro antimikrobiyal aktiviteleri test edilmiştir. Elde edilen sonuçlar 2-N-sübstite-1,4-naftakinonların yüksek antimikrobiyal etkinliğe sahip olduklarını göstermektedir. Bileşiklerin difüzyon kapasitesi de antimikrobiyal aktivitelerin belirlenmesinde önem taşımaktadır; Sonuçlar $\mathbf{2 c}$, $2 \mathbf{f}$ ve $\mathbf{2 g}$ bileşiklerinin gelecekteki çalışmalar için umut verici bileşikler olduklarını ortaya koymuştur.
\end{abstract}

Anahtar Kelimeler: 1,4-Naftakinon, nükleofilik yerdeğiştirme, antimikrobiyal aktivite

\section{INTRODUCTION}

Quinones are extremely important compounds due to their contributions to energy production and creating of vital links for the electron-transport system [1]. 2-Substituted-1,4-naphthoquinone derivatives have an important role in this class of compounds. The results obtained in a study on the antimicrobial activity of the 1,4-naphthoquinones showed that naphthaquinone core should have at least one electron donor group or a weak electron withdrawing group at the 2- or 3-position [2]. The electron donor group or electron withdrawing group increases the hydrogen-bonding capacity of naphthoquinones. Thus, increased hydrogen bonding capacity can facilitate molecular interactions and enhance the biological activity of these compounds. Therefore, biological activities of the 2-substituted-1,4-naphthoquinones have been studied in a wide range of studies [3]. In particular, 2-N-1,4-naphthoquinones exhibit a wide spectrum of pharmaceutical activity including molluscicidal, cytotoxic, anti-tumor and antibacterial activities [4]. For this reason, 2-N1,4-naphthoquinones are very important building blocks for the synthesis of many natural products and other biologically active compounds [5].

\footnotetext{
* Corresponding author. Email address: kiymet.berkilakar@gop.edu.tr http://dergipark.gov.tr/csj C2016 Faculty of Science, Cumhuriyet University
} 
In this article, we report the synthesis of new $2-\mathrm{N}$ 1,4-naphthoquinone derivatives (2a-2g). The compounds were characterized via various spectral methods. Finally, synthesized compounds were evaluated for their antimicrobial activity against C.albicans, C.utulis, B.subtilis, S.aureus, E.aerogenes, P.aurogirosa, B.cereus P.vulgaris, S.pyogenes, E.coli, K. pneumonia.

\section{EXPERIMENTAL}

\subsection{Chemistry}

2,5,8-Tribromo-1,4-naphthoquinone (1) was synthesized using known procedures [9]. Column chromatography was carried out using Merck 60 (70-230 Mesh) silica. Melting points were determined on an Electrothermal (IA9100) melting point apparatus. IR spectra were recorded on a Jasco FT/IR 430 instrument. Mass spectra were recorded on Agilent 6210 TOF LC/MS and GC-MS Perkin Elmer Clarus 500 under electron impact (EI) conditions. ${ }^{1} \mathrm{H}$ - and ${ }^{13} \mathrm{C}-\mathrm{NMR}$ spectra were recorded on 400 (100) $\mathrm{MHz}$ Bruker spectrometer and 600 (150) $\mathrm{MHz}$ Agilent spectrometer. The following abbreviations are used to indicate the multiplicities: s (singlet), $d$ (doublet), $\mathrm{t}$ (triplet), m (multiplet) and br s (broad singlet).

\subsubsection{General procedure for the reactions of} 2,5,8-tribromo-1,4-naphthoquinone (1) with nucleophiles

To a stirred solution of 2,5,8-tribromo-1,4naphthoquinone (1) (0.51 to $1.1 \mathrm{mmol})$ in the appropriate solvent (concentration was between 5.58-75.4 $\mathrm{mM}$ ) and at room temperature was added appropriate base ( 3 eq) (except the reaction performed with ethyl amine and $n$-butylamine) and the nucleophile (1.1 eq). Upon consumption of the starting material (monitored by TLC) the reaction mixture was diluted with water $(50 \mathrm{~mL})$ and extracted with dichloromethane $(3 \times 50 \mathrm{~mL})$. The combined organic layer was washed with water $(100 \mathrm{~mL})$ and dried over anhydrous sodium sulfate which was then filtered and concentrated in vacuum. For the preparation of $\mathbf{2} \mathbf{d}$ and $\mathbf{2 g}$, the resulting residue was purified via small column filtration (silica gel, hexane/EtOAc, 9:1) mixture as eluent. The product was finally recrystallized from dichloromethane to give compounds $\mathbf{2 a - 2 g}$.

\section{5,8-Dibromo-2-(methylamino)-1,4- naphthoquinone (2a):}

Dark red needle crystals, 69\%, $120 \mathrm{mg}, \mathrm{mp} 265-$ $267{ }^{\circ} \mathrm{C}, \mathrm{R}_{\mathrm{f}}=0.09$ (1:9 ethyl acetate/hexane), ${ }^{1} \mathrm{H}$ NMR $\left(400 \mathrm{MHz}, \mathrm{CDCl}_{3}\right) \delta 7.78$ (A part of the AB system, $J_{6,7}=8.8 \mathrm{~Hz}, 1 \mathrm{H}, \mathrm{H}_{6}$ ), 7.68 (B part of the AB system, $\left.J_{6,7}=8.8 \mathrm{~Hz}, 1 \mathrm{H}, \mathrm{H}_{7}\right), 5.88($ br s, $1 \mathrm{H}$, $\mathrm{NH}), 5.77\left(\mathrm{~s}, 1 \mathrm{H}, \mathrm{H}_{3}\right), 2.95\left(\mathrm{~d}, J_{\mathrm{NH}, \mathrm{CH} 3}=5.2 \mathrm{~Hz}, 3 \mathrm{H}\right.$, $\left.\mathrm{CH}_{3}\right) ;{ }^{13} \mathrm{C}$ NMR $\left(100 \mathrm{MHz}, \mathrm{CDCl}_{3}\right) \delta 180.0$, 179.7, 148.1, 141.6, 138.9, 132.9, 130.4, 122.1, $121.1,101.4,29.3$; IR $\left(v_{\max }, \mathrm{cm}^{-1}\right) 3293,3056$, 2929, 1675, 1643, 1606, 1542, 1496, 1419, 1371, $1322,1255,1214 ; 1166 ; 1133 ; 1089 ; 1068 ; 838$; 813; 754; 732; 680; 634; 566; 511; 482; 457; 435; 424; 404; HRMS (HPLC-TOF/MS) m/z 343.8148 $[\mathrm{M}+\mathrm{H}]^{+}, 367.7892[\mathrm{M}+\mathrm{Na}+2]^{+}$; Anal. Calcd. For $\mathrm{C}_{11} \mathrm{H}_{7} \mathrm{Br}_{2} \mathrm{NO}_{2}$ : C, 38.30; H, 2.05; N, 4.06. Found: C, 38.28; H, 2.05; N, 4.08 .

\section{5,8-Dibromo-2-(ethylamino)-1,4- naphthoquinone (2b):}

Dark red needle crystals, yield 96\%, $218 \mathrm{mg}, \mathrm{mp}$ $201-202{ }^{\circ} \mathrm{C}, \mathrm{R}_{\mathrm{f}}=0.14$ (1:9 ethyl acetate/hexane). ${ }^{1} \mathrm{H}$ NMR (400 MHz, $\mathrm{CDCl}_{3}$ ): $\delta 7.76$ (A part of the AB system, $J_{6,7}=9,2 \mathrm{~Hz}, \mathrm{H}_{6}$ ), 7.67 (B part of the AB system, $\left.J_{6,7}=9.2 \mathrm{~Hz}, \mathrm{H}_{7}\right), 5.76\left(\right.$ br s, $2 \mathrm{H}, \mathrm{H}_{3}$ and $\mathrm{NH}), 3.23\left(\mathrm{~m}, 2 \mathrm{H}, \mathrm{H}_{\mathrm{a}}\right), 1.35(\mathrm{t}, J=7.2 \mathrm{~Hz}, 3 \mathrm{H}$, $\left.\mathrm{H}_{\mathrm{b}}\right) ;{ }^{13} \mathrm{C}$ NMR $\left(100 \mathrm{MHz}, \mathrm{CDCl}_{3}\right) \delta 180.1,179.8$, $147.0,141.5,138.9,132.9,130.4,122.1,121.1$, $101.5,37.4,13.5$; IR $\left(v_{\max }, \mathrm{cm}^{-1}\right) 3384,3102$, 3054, 2969, 2933, 2869, 1671, 1637, 1542, 1498, $1390,1369,1342,1317,1263,1211,1149,1122$, 1083, 1064, 1010, 865, 823, 742, 582, 545, 518, 478; HRMS (HPLC-TOF/MS) m/z 357.8385 $[\mathrm{M}+\mathrm{H}]^{+}, 381.8135[\mathrm{M}+\mathrm{Na}+2]^{+}$; Anal. Calcd. For $\mathrm{C}_{12} \mathrm{H}_{9} \mathrm{Br}_{2} \mathrm{NO}_{2}$ : C, 40.15; H, 2.53; N, 3.90. Found: C, 39.99; H, 2.52; N, 3.92 .

\section{5,8-Dibromo-2-butylamino-1,4-} naphthoquinone (2c):

Orange needle crystals, yield 49\%, $210 \mathrm{mg}$, mp $115-117{ }^{\circ} \mathrm{C}, \mathrm{R}_{\mathrm{f}}=0.36$ (1:9 ethyl acetate/hexane). 
${ }^{1} \mathrm{H}$ NMR $\left(400 \mathrm{MHz}, \mathrm{CDCl}_{3}\right) \delta 7.76$ (A part of the AB system, $\left.J_{6,7}=8.8 \mathrm{~Hz}, 1 \mathrm{H}, \mathrm{H}_{6}\right), 7.66$ (B part of the $\mathrm{AB}$ system, $\left.J_{6,7}=8.8 \mathrm{~Hz}, 1 \mathrm{H}, \mathrm{H}_{7}\right), 5.82(\mathrm{br} \mathrm{s}$, $1 \mathrm{H}, \mathrm{NH}), 5.76\left(\mathrm{~s}, 1 \mathrm{H}, \mathrm{H}_{3}\right), 3.18\left(\mathrm{~m}, 2 \mathrm{H}, \mathrm{CH}_{2}\right)$, $1.68\left(\mathrm{~m}, 2 \mathrm{H}, \mathrm{CH}_{2}\right), 1.45\left(\mathrm{~m}, 2 \mathrm{H}, \mathrm{CH}_{2}\right), 0.98(\mathrm{t}$, $\left.3 \mathrm{H}, \mathrm{CH}_{3}\right) ;{ }^{13} \mathrm{C} \mathrm{NMR}\left(100 \mathrm{MHz}, \mathrm{CDCl}_{3}\right) \delta 180.0$, $179.9,147.1,141.6,138.9,132.9,130.3,122.1$, 121.1, 101.4, 42.4, 30.3, 20.2, 13.7; IR ( $v_{\max }, \mathrm{cm}^{-}$ 1) 3382, 3052, 2960, 2931, 2871, 1670, 1643, $1542,1508,1477,1365,1315,1257,1209,1145$, 1074, 848, 817, 418, 401; HRMS (HPLCTOF/MS) m/z $385.8525[\mathrm{M}+\mathrm{H}]^{+}$; Anal. Calcd. For $\mathrm{C}_{14} \mathrm{H}_{13} \mathrm{Br}_{2} \mathrm{NO}_{2}$ : C, 43.44; $\mathrm{H}, 3.39 ; \mathrm{N}, 3.62$. Found: C, 43.31; H, 3.37; N, 3.64.

\section{5,8-Dibromo-2-(phenylamino)-1,4- naphthoquinone (2d):}

Dark red needle crystals, yield 56\%, $198 \mathrm{mg}$, mp 153-155 ${ }^{\circ} \mathrm{C}, \mathrm{Rf}=0.41(1: 9$ ethyl acetate/hexane $)$, ${ }^{1} \mathrm{H}$ NMR $\left(400 \mathrm{MHz}, \mathrm{CDCl}_{3}\right) \delta 7.81$ (A part of the AB system, $J_{6,7}=8.4 \mathrm{~Hz}, 1 \mathrm{H}, \mathrm{H}_{6}$ ), 7.74 (B part of the AB system, $\left.J_{6,7}=8.4 \mathrm{~Hz}, 1 \mathrm{H}, \mathrm{H}_{7}\right), 7.53$ (br s, $1 \mathrm{H}, \mathrm{NH}), 7.48-7.44\left(\mathrm{~m}, 2 \mathrm{H}, \mathrm{H}_{\mathrm{a}}\right), 7.28-7.23(\mathrm{~m}$, $3 \mathrm{H}, \mathrm{H}_{\mathrm{b}}$ and $\left.\mathrm{H}_{\mathrm{c}}\right), 6.45\left(\mathrm{~s}, 1 \mathrm{H}, \mathrm{H}_{3}\right) ;{ }^{13} \mathrm{C}$ NMR $(100$ $\left.\mathrm{MHz}, \mathrm{CDCl}_{3}\right) \delta 181.1,179.9,141.7,139.3,137.3$, $130.2,129.8$ (2C), 128.0, 125.8, 122.5 (2C), 122.4, 121.2, 117.9, 104.2; IR $\left(v_{\max }, \mathrm{cm}^{-1}\right) 3369$, 2954, 2923, 2852, 1731, 1668, 1635, 1596, 1540, 1508, 1457, 1369, 1253, 1193, 1124, 1074, 819, 734, 688, 565, 543, 453, 416, 401; HRMS

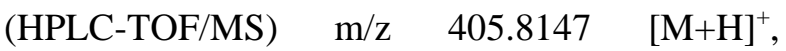
$429.1645 \quad[\mathrm{M}+\mathrm{Na}]^{+}$; Anal. Calcd. For $\mathrm{C}_{16} \mathrm{H}_{9} \mathrm{Br}_{2} \mathrm{NO}_{2}$ : C, 47.21; H, 2.23; N, 3.44. Found: $\mathrm{C}, 47.05 ; \mathrm{H}, 2.23 ; \mathrm{N}, 3.42$

\section{2-(Benzylamino)-5,8-dibromo-1,4- naphthoquinone (2e):}

Orange needle crystals, yield 59\%, $250 \mathrm{mg}$, mp 136- $138{ }^{\circ} \mathrm{C}, \mathrm{R}_{\mathrm{f}}=0.24$ (1:9 ethyl acetate/hexane). ${ }^{1} \mathrm{H}$ NMR (400 MHz, $\left.\mathrm{CDCl}_{3}\right) \delta 7.78$ (A part of the AB system, $J_{6,7}=8.8 \mathrm{~Hz}, 1 \mathrm{H}, \mathrm{H}_{6}$ ), 7.68 (B part of the $\mathrm{AB}$ system, $\left.J_{6,7}=8.8 \mathrm{~Hz}, 1 \mathrm{H}, \mathrm{H}_{7}\right), 7.42-7.32$ $\left(\mathrm{m}, 3 \mathrm{H}, \mathrm{H}_{\mathrm{a}}, \mathrm{H}_{\mathrm{b}}\right.$ and $\mathrm{H}_{\mathrm{c}}$ ), 6.16 (br s, $1 \mathrm{H}, \mathrm{NH}$ ), 5.83 $\left(\mathrm{s}, 1 \mathrm{H}, \mathrm{H}_{3}\right), 4.38\left(\mathrm{~d}, J_{\mathrm{NH}, \mathrm{CH} 2}=5.6 \mathrm{~Hz}, \mathrm{CH}_{2}\right) ;{ }^{13} \mathrm{C}$ NMR $\left(100 \mathrm{MHz}, \mathrm{CDCl}_{3}\right) \delta 180.1,179.7,146.9$, $141.6,139.0,135.7,132.8,130.3,129.1$ (2C),
128.2, 127.6 (2C), 122.1, 121.2, 102.5, 46.9; IR $\left(v_{\max }, \mathrm{cm}^{-1}\right) 3550,3477,3394,3058,1675,1631$, $1619,1542,1496,1452,1367,1317,1259,1205$, $1135,1083,1068,1043,860,821,732,700,613$, 543, 478, 443, 426; HRMS (HPLC-TOF/MS) m/z $419.8293 \quad[\mathrm{M}+\mathrm{H}]^{+} ; \quad$ Anal. Calcd. For $\mathrm{C}_{17} \mathrm{H}_{11} \mathrm{Br}_{2} \mathrm{NO}_{2}$ : C, 48.49; $\mathrm{H}, 2.63 ; \mathrm{N}, 3.33$. Found: C, 48.38; H, 2.64; N, 3.34.

\section{5,8-Dibromo-2-(phenylethylamino)-1,4- naphthoquinone (2f):}

Dark red needle crystals, yield $99 \%, 165 \mathrm{mg}, \mathrm{mp}$ $157-159{ }^{\circ} \mathrm{C}, \mathrm{R}_{\mathrm{f}}=0.17$ (1:9 ethyl acetate/hexane). ${ }^{1} \mathrm{H}$ NMR $\left(400 \mathrm{MHz}, \mathrm{CDCl}_{3}\right) \delta 7.76$ (A part of the AB system, $\left.J_{6,7}=8.6 \mathrm{~Hz}, 1 \mathrm{H}, \mathrm{H}_{6}\right), 7.66(\mathrm{~B}$ part of the $\mathrm{AB}$ system, $\left.J_{6,7}=8.6 \mathrm{~Hz}, 1 \mathrm{H}, \mathrm{H}_{7}\right), 7.38-7.35$ $\left(\mathrm{m}, 2 \mathrm{H}, \mathrm{H}_{\mathrm{c}}\right), 7.30-7.24\left(\mathrm{~m}, 3 \mathrm{H}, \mathrm{H}_{\mathrm{d}}\right.$ and $\left.\mathrm{H}_{\mathrm{c}}\right), 5.86$ (s, 1H, NH), 5.81(s, 1H, H3), $3.45(\mathrm{t}, 2 \mathrm{H}, \mathrm{H}), 2.99$ $\left(\mathrm{t}, J_{\mathrm{a}, \mathrm{b}}=7 \mathrm{~Hz}, 2 \mathrm{H}, \mathrm{H}_{\mathrm{b}}\right) ;{ }^{13} \mathrm{C}$ NMR $(100 \mathrm{MHz}$, $\left.\mathrm{CDCl}_{3}\right) \delta 180.1,179.6,146.9,141.6,138.9,137.7$, 132.7, 130.3, 128.9 (2C), 128.6 (2C), 127.0, 122.1, 121.1, 101.8, 43.7, 34.4; IR $\left(v_{\max }, \mathrm{cm}^{-1}\right)$ 3297, 3052, 3019, 2991, 2902, 2881, 2840, 1677, $1627,1610,1540,1506,1452,1365,1321,1247$, 1218, 1132, 1074, 838, 823, 808, 746, 728, 698, 551, 514, 485, 416; HRMS (HPLC-TOF/MS) m/z $433.8562[\mathrm{M}+\mathrm{H}]^{+}, 455.8337 \quad[\mathrm{M}+\mathrm{Na}]^{+}$; Anal. Calcd. For $\mathrm{C}_{18} \mathrm{H}_{13} \mathrm{Br}_{2} \mathrm{NO}_{2}$ : C, 49.69; H, 3.01; N, 3.22. Found: C, 49.51; H, 3.00; N, 3.24.

\section{5,8-Dibromo-2-[(4-hydroxyphenyl)amino]-1,4-} naphthoquinone (2g):

Black powder, yield 60\%, $193 \mathrm{mg}$, mp 245-247 ${ }^{\circ} \mathrm{C}, \mathrm{R}_{\mathrm{f}}=0.13$ (2:8 ethyl acetate/hexane). ${ }^{1} \mathrm{H}$ NMR $\left(400 \mathrm{MHz}, \mathrm{DMSO}-\mathrm{d}_{6}\right) \delta 9.59(\mathrm{~s}, 1 \mathrm{H}, \mathrm{OH}), 9.16(\mathrm{~s}$, $1 \mathrm{H}, \mathrm{NH}$ ), 7.89 (A part of the AB system, $J_{6,7}=8.4$ $\mathrm{Hz}, 1 \mathrm{H}, \mathrm{H}_{6}$ ), 7.83 (B part of the AB system, $J_{6,7}$ $\left.=8.4 \mathrm{~Hz}, 1 \mathrm{H}, \mathrm{H}_{7}\right), 7.14$ (A part of the $\mathrm{AB}$ system, $\left.J_{\mathrm{a}, \mathrm{b}}=8 \mathrm{~Hz}, 2 \mathrm{H}, \mathrm{H}_{\mathrm{b}}\right), 6.82(\mathrm{~B}$ part of the $\mathrm{AB}$ system, $\left.J_{\mathrm{a}, \mathrm{b}}=8 \mathrm{~Hz}, 2 \mathrm{H}, \mathrm{H}_{\mathrm{a}}\right), 5.85\left(\mathrm{~s}, 1 \mathrm{H}, \mathrm{H}_{3}\right) ;{ }^{13} \mathrm{C}$ NMR $\left(100 \mathrm{MHz}, \mathrm{DMSO}_{-} \mathrm{d}_{6}\right) \delta 180.3,180.0$, $155.7,147.2,141.7,139.6,132.6,131.3,129.4$, 125.9 (2C), 121.6, 120.1, 116.3 (2C), 101.8; IR $\left(v_{\max }, \mathrm{cm}^{-1}\right) 3318,3097,3052,1731,1683,1621$, $1602,1590,1538,1513,1438,1371,1317,1297$, $1251,1228,1195,1166,1124,1087,1004,875$, 
$835,821,806,752,740,709,671,628,534,512$, 497, 437; HRMS (HPLC-TOF/MS) m/z 421.8090 $[\mathrm{M}+\mathrm{H}]^{+}$; Anal. Calcd. For $\mathrm{C}_{16} \mathrm{H}_{9} \mathrm{Br}_{2} \mathrm{NO}_{3}$ : C, 45.42; H, 2.14; N, 3.31. Found: C, 45.24; H, 2.13; N, 3.30 .

2.2. In vitro antimicrobial studies of 5,8dibromo-2-N-naphthoquinone derivatives

The bacteria; Staphylococcus aureus, Bacillus subtilis, Escherichia coli, Pseudomonas aeruginosa, Proteus vulgaris, Klebsiella pneumonia, and yeasts; Candida albicans, $C$. utilis, was obtained from the culture collection of Industrial Microbiology and Biotechnology Laboratory of Gaziosmanpasa University. The strains were maintained on Brain Heart Infusion (BHI) agar medium or Potato Dextrose Agar (PDA) at $4{ }^{\circ} \mathrm{C}$ until they were used in the tests [10].

Test microorganisms incubated for $18 \mathrm{~h}$ at $36 \pm 1$ ${ }^{\circ} \mathrm{C}$ were called activated cultures. After the concentrations of the activated bacteria and yeast were adjusted to $10^{8} \mathrm{cfu} / \mathrm{mL}$ and $10^{6} \mathrm{cfu} / \mathrm{mL}$ consequently, antimicrobial activity of the chemicals was tested by the spot on lawn method [11]. $10 \mu \mathrm{L}$ of chemical suspensions in concentrations with $1 \mu \mathrm{g} / \mu \mathrm{L}$ were spotted on inoculated and air-dried Mueller Hinton Agar (MHA) plates and the halozones of the inhibition were measured in $\mathrm{mm}$ following the incubation at $36{ }^{\circ} \mathrm{C}$ for $24 \mathrm{~h}$.

Minimum Inhibitory Concentrations (MIC) of the chemicals were determined via the agar spot method of Wiegand [12] with modifications. 10 $\mu \mathrm{L}$ of chemicals in a concentration range of $15.31-1000 \mu \mathrm{g} / \mathrm{mL}$ in appropriate solutions (water or dimethyl sulfoxide (DMSO)) were tested against activated microorganisms. The lowest concentration at invisible inhibition zone was taken as the MIC value. Ampicillin $(100 \mu \mathrm{g})$ was used as positive control and $\mathrm{KCN}$ suspension or DMSO was used as negative control. Each test was run in triplicate.

\section{RESULTS AND DISCUSSION}

\subsection{Synthesis}

A new series of 2-N-1,4-naphthoquinone derivatives (2a-2g) were synthesized via nucleophilic substitution reaction of 2,5,8tribromonaftalin-1,4-dion (1) and one of the following nucleophiles according to known methods with minor modification [6-8]: methylamine, ethtylamine, $n$-buthylamine, 4aminophenol, phenylethylamine, aniline and benzylamine (Figure 1 and Table 1). The characterizations of the compounds were performed using ${ }^{1} \mathrm{H}$ and ${ }^{13} \mathrm{C}$ NMR spectroscopy, elemental analysis, mass spectrometry and IR spectroscopy.
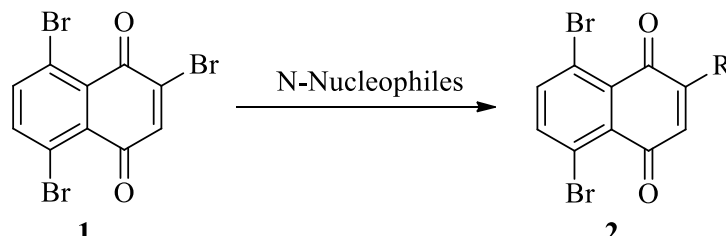

$$
\begin{array}{ll}
\mathbf{2 a} & \mathrm{R}=\mathrm{NHCH}_{3} \\
\mathbf{2 b} & \mathrm{R}=\mathrm{NHCH}_{2} \mathrm{CH}_{3} \\
\mathbf{2 c} & \mathrm{R}=\mathrm{NH}\left(\mathrm{CH}_{2}\right)_{3} \mathrm{CH}_{3}, \\
\mathbf{2 d} & \mathrm{R}=\mathrm{NHC}_{6} \mathrm{H}_{5} \\
\mathbf{2 e} & \mathrm{R}=\mathrm{NHCH}_{2} \mathrm{C}_{6} \mathrm{H}_{5} \\
\text { 2f } & \mathrm{R}=\mathrm{NH}\left(\mathrm{CH}_{2}\right)_{2} \mathrm{C}_{6} \mathrm{H}_{5} \\
\text { 2g } & \mathrm{R}=\mathrm{NHC}_{5} \mathrm{H}_{4} \mathrm{OH}
\end{array}
$$

Figure 1. Reaction scheme for the preparation of 5,8dibromo-2-N-substituted-1,4-naphthoquinones.

Analysis of the ${ }^{1} \mathrm{H}$ NMR in $\mathrm{CDCl}_{3}$ showed the formation of the $\mathbf{2} \mathbf{a}-\mathbf{2} \mathbf{g}$ by the presence of signals attributed to the $\mathrm{H}_{3}$ and $\mathrm{NH}$ protons. Furthermore, while the two protons on the aromatic ring in the 2,5,8-tribromonaftalin-1,4-dion (1) appear as a singlet at $7.8 \mathrm{ppm}$ [9], these protons give an $\mathrm{AB}$ system after attaching to an electron donor group in position 2 of the compound. ${ }^{13} \mathrm{C}$ NMR spectra are also in agreement with the proposed structures. 
Table 1. Synthesis of 5,8-dibromo-2-N-substituted-1,4-naphthoquinones.

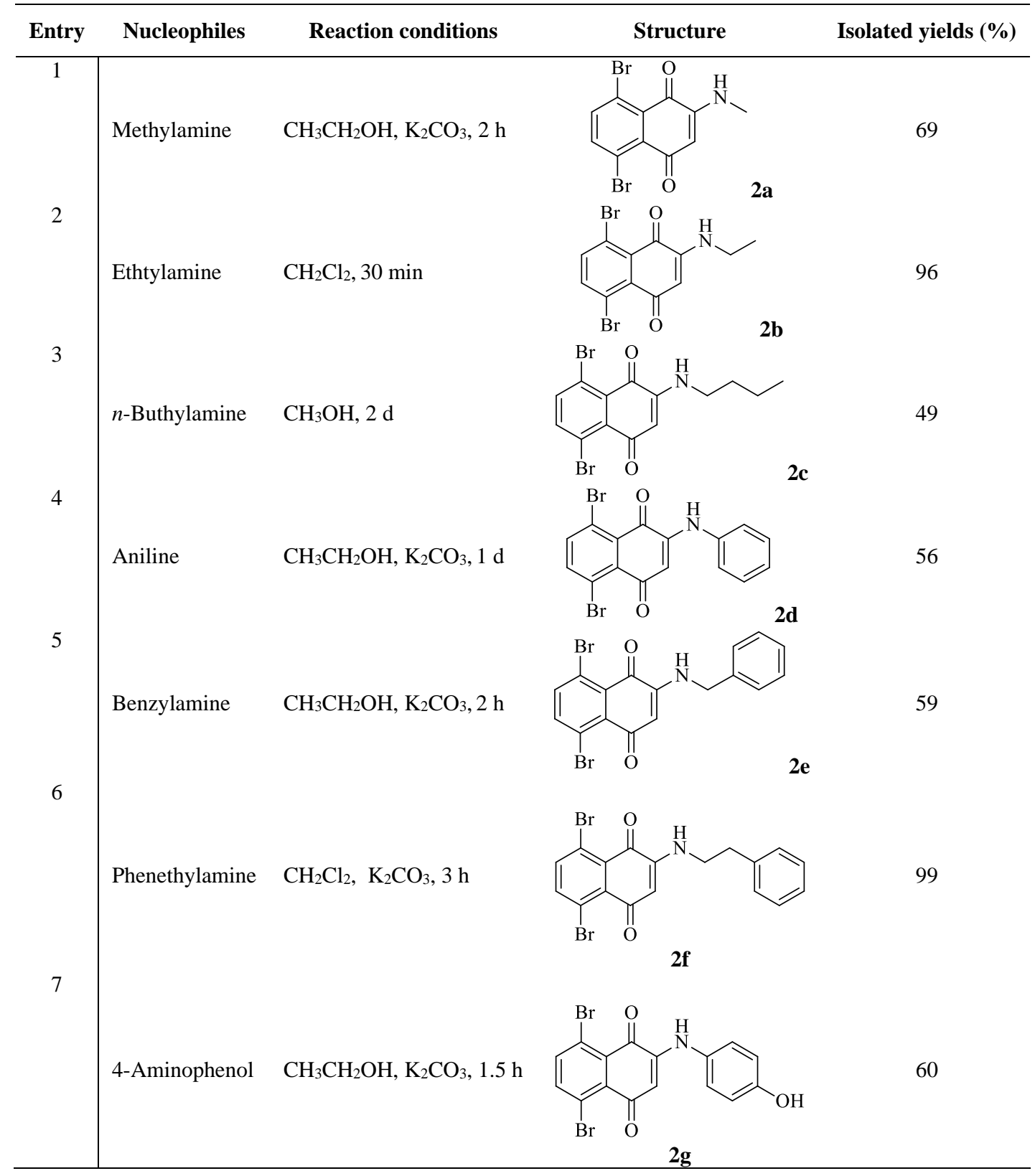

\subsection{Antimicrobial activity}

The antimicrobial activities of the synthesized 2amino-1,4-naphthoquinone derivatives (2a-2g) were determined using agar spot tests. The experiment was repeated three times and the arithmetic mean of the MIC values are given in Table 2 .

The compound $\mathbf{2 c}$ is highly active against yeast but also shows antibacterial activity to gram (+) bacteria and gram (-) bacteria (Table 2). When it is compared to the other chemicals, the antimicrobial effect of $\mathbf{2 c}$ on pathogenic $P$. vulgaris is highly taking attention which is followed by $\mathbf{2 g}$.

Even the data obtained from minimum inhibition concentration of the compounds showed the highest activity against $P$. vulgaris $(\mathbf{2} \mathbf{c}>\mathbf{2 g}>\mathbf{2 e})$, the diameters of the inhibition zone of the compounds didn't have the same performance; $\mathbf{2 f}$ $(13 \mathrm{~mm})>\mathbf{2 b}(12 \mathrm{~mm})=\mathbf{2 e}(12 \mathrm{~mm})=\mathbf{2} \mathbf{g}(12 \mathrm{~mm})$ $>\mathbf{2 c}(10 \mathrm{~mm})=\mathbf{2 d}(10 \mathrm{~mm})$. The same results also 
obtained from the MIC test against B.subtilis $(\mathbf{2 g}$ $>\mathbf{2 a}=\mathbf{2} \mathbf{c}=\mathbf{2} \mathbf{d}$ ). It is also shown that the diameters of the inhibition zone of compounds are not correlated in MIC values $(\mathbf{2 f}(16 \mathrm{~mm})>\mathbf{2 g}$ $(15 \mathrm{~mm})>\mathbf{2 d}(13 \mathrm{~mm})=\mathbf{2 e}(13 \mathrm{~mm})>\mathbf{2 c}(12 \mathrm{~mm})$ $>\mathbf{2 b}(10 \mathrm{~mm}))$.

The highest size of the inhibition zones was recorded for C. utilis (Kuen1031) which are in the following order (upper than $10 \mathrm{~mm}): \mathbf{2 f}(22 \mathrm{~mm})$ $>\operatorname{Amp}(20 \mathrm{~mm})>\mathbf{2 g}(14 \mathrm{~mm})=\mathbf{2 c}(14 \mathrm{~mm})>\mathbf{2 e}$ $(13 \mathrm{~mm})>\mathbf{2 d}(12 \mathrm{~mm})>\mathbf{2 a}(11 \mathrm{~mm})>\operatorname{DMSO}(0$ $\mathrm{mm})$. The halo zones of inhibition upper than 10 $\mathrm{mm}$ for $S$. aureus (ATCC 25213) are in the following order: $\mathbf{2 f}(22 \mathrm{~mm})>\operatorname{Amp}(20 \mathrm{~mm})>\mathbf{2 d}$ $(16 \mathrm{~mm})>\mathbf{2 e}(15 \mathrm{~mm})>\mathbf{2 g}(12 \mathrm{~mm})>\operatorname{DMSO}(0$ $\mathrm{mm})$. The diameter of the zone against $P$. vulgaris (Kuen1329) is lower than C. utilis (Kuen1031) or S. aureus (ATCC 25213) for $\mathbf{2 f}(13 \mathrm{~mm})$.

According to Table 2, it is obvious that $\mathbf{2 c}$ has the lowest MIC against the yeasts and P.vulgaris, and $\mathbf{2 g}$ for B.subtilis, however the inhibition zone of $\mathbf{2 f}$ is larger general. This may be due to the higher diffusion capacity of $\mathbf{2} \mathbf{f}$ in comparison with $\mathbf{2 c}$ and 2g.

Table 2. Minimum inhibitory concentration of synthesized 2-N-substituted-1,4-naphthoquinones $\mathbf{2 a - 2 g}$.

\begin{tabular}{lllllllll}
\hline \multicolumn{7}{c}{ MIC $\left(\boldsymbol{\mu g} \mathbf{~ m L}^{-\mathbf{1}}\right)$} \\
\hline Comp. & C. albicans & C. utilis & B. subtilis & S. aureus & P. aurogirosa & P. vulgaris & E.coli & K. pneumonia \\
\hline $\mathbf{2 a}$ & 500 & 250 & 125 & 125 & 125 & $1000+$ & 125 & $1000+$ \\
$\mathbf{2 b}$ & 125 & 500 & 250 & 500 & 125 & 500 & 250 & 125 \\
$\mathbf{2 c}$ & 15,3125 & 15,3125 & 125 & 250 & 250 & 15,3215 & 500 & 250 \\
$\mathbf{2 d}$ & 1000 & 1000 & 125 & 1000 & 500 & 500 & $1000+$ & $1000+$ \\
$\mathbf{2 e}$ & 500 & 500 & 250 & 250 & 500 & 125 & 125 & 1000 \\
$\mathbf{2 f}$ & $1000+$ & 250 & 500 & 125 & 125 & 250 & 125 & 250 \\
$\mathbf{2 g}$ & 125 & 125 & 61,25 & 125 & 125 & 61,25 & 125 & $1000+$ \\
DMSO & 0 & 0 & 0 & 0 & 0 & 0 & 0 & 0
\end{tabular}

In this study, buthylamino (2c), phenylethylamino (2f) and hydroxyphenyl (2g) groups showed best activity. The activity is significantly increased with an increase in the length of the carbon chain $(\mathbf{2 a}, \mathbf{2 b}$ and $\mathbf{2 c})$. But, the increase in length of the carbon chain and the increase in activity is not proportional, it is irregular. The activity is markedly reduced when the alkyl group is replaced by a phenyl ring (2d). In addition, the presence of methylene groups between the phenyl and $\mathrm{NH}$ groups (2e and $\mathbf{2 f}$ ) had a positive effect on the antimicrobial activity. Also, substitution of electron-donating hydroxy group at the para position of the phenyl ring (2g) resulted in a profound increase in activity.

\section{CONCLUSION}

In conclusion, we report on the synthesis and characterized of a series of new 2-N-substituted naphthoquinones 2a-2g. As a result, it is obvious that $2 \mathbf{c}, \mathbf{2 f}$ and $2 \mathrm{~g}$ have promising activity for future works. In general, 2-N-substituted-1,4naphthoquinones which are synthesized in this work have high activity. However, $2 \mathbf{f}$ and $\mathbf{2 g}$ are especially suggested for antifungal activity.

\section{Acknowledgement}

The authors thank to the Gaziosmanpaşa University Research Projects Foundation (Grant number: 2014/36). 


\section{REFERENCES}

[1] Hodnett E.M., Wongwiechintana C., Dunn III W.J., Marrs P., Substituted 1,4naphthoquinones vs. the ascitic sarcoma 180 of mice, J. Med. Chem., 26 (1983) 570-574.

[2] Gershon H. and Shanks L., Fungitoxicity of 1,4-naphthoquinones to candida albicans and trichophyton menthagrophytes, Can. J. Microbiol., 21 (1975) 1317-1320.

[3] Riffel A., Medina L.F., Stefani V., Santos R.C., Bizani D., Brandelli A., In vitro antimicrobial activity of a new series of 1,4naphthoquinones, Braz. J. Med. Biol. Res., 35 (2002) 811-818.

[4] Aeken S.V., Deblander J., Houwer J.D., Mosselmans T., Tehrani K.A., Unexpected reaction of 2-amino-1,4-naphthoquinone with aldehydes: new synthesis of naphtho[2,1-d]oxazole compounds, Tetrahedron 67 (2011) 512-517.

[5] Liu B. and Ji S-J., Facile synthesis of 2amino-1,4-naphthoquinones catalyzed by molecular iodine under ultrasonic irradiation, Synth. Commun., 38 (2008) 1201-1211.

[6] Tandon V.K., Maurya H.K., Mishra N.N., Shukla P.K., Design, synthesis and biological evaluation of novel nitrogen and sülfür containing hetero-1,4naphthoquinones as potent antifungal and antibacterial agents, Eur. J. Med. Chem., 44 (2009) 3130-3137.

[7] Bolognesi M.L., Lizzi F., Perozzo R., Brun R., Cavalli A., Synthesis of a small library of 2-phenoxy-1,4-naphthoquinone and 2phenoxy-1,4-anthraquione derivatives bearing anti-trypanosomal and antileishmanial activity, Bioorg. Med. Chem. Lett., 18 (2008) 2272-2276.

[8] Sayil C. and Ibis C., Synthesis and spectral properties of novel thionaphtoquinone dyes, Bull. Korean Chem. Soc.; 31 (2010) 12331236.

[9] Çakmak O., Berkil Akar K., Kaplan N., Functionalization of naphthalene: a novel synthetic route to brominated naphthoquiones, Arkivoc, 50 (2012) 274281.

[10] Andrews J.M., Determination of minimum inhibition concentrations, J. Antimicrob. Chemother., 48 (2001) Suppl.S1, 5-16.

[11] Karadag A., Aydın A., Dede S., Tekin S., Yanar Y., Cadirci B.H., Soylu M.S., Andac O., Five novel dicyanidoaurate(I)-based complexes exhibiting significant biological activities: synthesis, characterization and three crystal structures, New J. Chem., 39 (2015) 8136-8152.

[12] Wiegand I., Hilpert K., Hancock R.E.W., Agar and broth dilution methods to determine the minimal inhibitory concentration (MIC) of antimicrobial substances, Nat. Protoc., 3/2 (2008) 163175. 